\title{
Brazilian Undergraduate Students' Conceptions on the Origins of Human Social Behavior: Implications for Teaching Evolution
}

\author{
Filipe Cavalcanti da Silva Porto ${ }^{1 *}$, Paulo Cesar Paiva ${ }^{2}$, Ricardo F Waizbort ${ }^{3}$ \\ and Maurício Roberto Motta Pinto da Luz
}

\begin{abstract}
Students' conceptions on the origins of human social behavior are poorly understood. The aim of this research was to quantitatively evaluate the conceptions on the origins of certain types of human behavior expressed by a group of 1,212 Brazilian university students. Results suggest that regardless of either religiosity or evolutionary commitments, the majority of the students advocate nurture-based arguments to explain human social behavior. Data also suggest that behaviors considered to be typically human are better explained by nurture-based arguments. The preference for nurture-based explanations may be due to the absence of the theme "behavior" in biology curriculum in secondary schools. The possibility of teaching aspects of human biology that are known to be influenced both by nature and nurture-based explanations is discussed. We conclude that, despite the enormous influence of evolutionary theory on recent western thought, Brazilian students do not seem to perceive its legacy concerning the origins of human social behavior.
\end{abstract}

Keywords: Nature/nurture debate, Human behavior, Evolution teaching, Biology teaching

\section{Background}

Behavior, and especially human behavior, is a multifactor phenomenon. In other words it may be explained by different disciplines, such as genetics, embryonic development, education, culture, etc. (Krebs 2003). It would be reasonable to expect that the development of each of these disciplines with regards to human behavior could have contributed to a less deterministic understanding of human behavior. Nevertheless, history tells us the opposite. At the beginning of the twentieth century, developments in genetics were sometimes manipulated to sustain social discrimination based on criteria of race and gender (Gould 1996; Stepan 2005). The opposition to these distorted applications of evolutionary theory probably led to stigma attached to any form of research that focused on biological or evolutionary theories to explain human

\footnotetext{
*Correspondence: portofilipe@gmail.com

${ }^{1}$ Colégio de Aplicação, Universidade Federal do Rio de Janeiro, Rua Batista da Costa, 55, Lagoa, Rio de Janeiro, RJ CEP: 22470-130, Brazil Full list of author information is available at the end of the article
}

behavior (Mayr 1982; Segerstrale 2000). Since the 1960s, extensive literature in several scientific fields such as evolutionary biology (Hamilton 1964; Trivers 1971, 1972), evolutionary psychology (Barkow et al. 1992; Buss 2005) and ethology (De Waal 1999, 2005; Wilson 1975) suggests that evolution through natural selection has major importance in explaining the roots of human nature (human universal behaviors; common to different cultures) including social behaviors such as love and altruism. However, claims about the importance of natural selection do not mean that acquired experience should be disregarded. Indeed, in his extensive review on the subject Ridley (2003) states that: "Human nature is indeed a combination of Darwin's universals, Galton's heredity, James's instincts, De Vries's genes, Pavlov's reflexes, Watson's associations, Kraepelin's history, Freud's formative experience, Boas' culture, Durkheim's division of labor, Piaget's development, and Lorenz's imprinting.(...) No account of human nature would be complete without them all". 
Still, consensus on the relative importance of phylogenetic and ontogenetic (developmental) factors and the different levels of selection involved in the biological origins of human behavior has not yet been reached among behavioral, genetic and evolutionary researchers (Buller 2005; Gould and Lewontin 1979; Jablonka and Lamb 2005; Laraia 2003 [1986]; Lickliter and Honeycutt 2003a, b; Krebs 2003; Rose and Rose 2000; Tooby et al. 2003). Researchers also diverge about the general public's conceptions of the origins of human behavior. One group claims that the public as a whole consider naturebased (genetic) arguments as predominant. The views of this group include the approaches of at least two kinds of researchers: those from humanities-for whom human behavior is completely explained by nurture-based explanations (education, social and cultural) (Laraia 2003 [1986]) - and some evo-devo (evolutionary developmental biology) behavioral researchers (Jablonka and Lamb 2005; Lickliter and Honeycutt 2003a). On the other hand, Patrick Bateson, another evo-devo researcher, believes that both nature and nurture arguments are equally acceptable by the public (Bateson 2001). Finally, there are authors that advocate that evolution by natural selection at the genetic level aspects should also be considered as a determinant for universal human behavior (e.g., Pinker 2002). Those authors usually claim that the public is more favorable to nurture-based explanations of human behavior.

Despite this intense debate, there is little empirical evidence to support either of the claims regarding how the general public thinks about the determinants of some human behaviors. Indeed, the first report in 1985 was based on data gathered from a sample of 308 individuals heterogeneous in terms of age, education, occupation, social status, voting and religious preferences. The results suggest that public opinion favors nurture-based reasoning when psychological problems (e.g., alcoholism, phobias and depression), beliefs (e.g., political, religious and racial), and personality traits (e.g., extroversion, neuroticism and shyness) are taken into account (Furnham et al. 1985). Nevertheless, with regard to psychological abilities or skills (e.g., intelligence, memory, sports and art), the same subjects tend to consider both nature and nurture, but with a slight inclination towards nature-based explanations.

In 1998 a meta-analysis of poll trends found that the majority of the respondents (from 65 to $90 \%$ ) choose nurture related factors (society, environment, upbringing and culture) as primary determinants of the following forms of behavior: child's personality, general behavior, sexual orientation, criminal behavior, and success in life (Singer et al. 1998). The sole exception was intelligence: $45 \%$ of the respondents answered that genes are more important while $52 \%$ favored nurture-based explanations.

Reports on human abilities tend to show a more balanced view of nature and nurture factors. In Tremblay and Gagné's (2001) study, 242 talented students from academic, dance and music areas recruited in college and high schools were asked about the heritability of academic, musical, and dance abilities on a 0 (behavior had no heritability at all) to 100 (complete heritability) scale. The average obtained varied from 44.3 for musical to 49.1 for academic ability. However, these averages are misleading because only $40 \%$ of the values were close to the average (between 40 and 60). So, in this case there were two important minorities of strong 'environmentalist' (close to the nurture extreme) and strong 'hereditarianist' (close to the nature extreme) and the larger group with a more equilibrated view of nature and nurture arguments. Accordingly, Parrott et al. (2003) report, that among 77 adults (18-45 years old), mean attribution of genetic influence on mental abilities (intelligence, mathematics and scientific) was $40.42 \%$. For talents such as athletic, musical and artistic, however, mean attribution for nature-based explanations was $26.25 \%$.

In summary, research on perceptions of the general public of human behavior has been focused on the origins of abilities, personality traits, beliefs, and psychological attributes. Data suggest that people tend to prefer nurture-based explanations when considering the origins of beliefs, psychological problems, and personality traits. In the case of abilities, people tend to consider both nature and nurture-based explanations, but more extreme opinions are not infrequent. It is important to highlight that people's perceptions of the origins of human social behaviors (any behavior that implies interactions between individuals) have not yet been investigated.

What are the implications for biology education from this debate? Secondary biology courses generally have a very minor focus on behavior (Rowland 2007; Silva-Porto et al. 2007). Nevertheless, young people are fascinated by themselves, by the human species, their own origin and their future (Alles and Stevenson 2003; Besterman and Baggot la Velle 2007; Nickels 1998; Rowland 2007). Moreover, young people are fascinated by behavior (their own and that of animals) and preoccupied with their social groups. Why not focus on the origins of social behavior in humans and other animals (Rowland 2007)? We believe that teachers should be aware of student's conceptions about the origins of human behavior.

In this paper we report quantitative data gathered from 1212 Brazilian university students to address three research questions, as follows: 
1. Where, in the nature-nurture continuum, lie the students' views on the origins of human behavior?

According to Pierre Bourdieu the settlement of a dominant concept in a certain historical period is only entirely understood if it permeates the educational system (Bourdieu 1998). Since behavior, and therefore human behavior, is virtually absent in most Brazilian high school biology textbooks (Silva-Porto et al. 2007), our hypothesis is that Brazilian students would mainly prefer nurture-based explanations for the origins of human behavior and disregard heredity.

2. What, if any, are the influences of religiosity and/or of the acceptance of human evolution on the students' views of the origins of human behavior?

The majority of Brazilians are Catholic and their religious commitments do not necessarily exclude general evolutionary explanations (Penteado et al. 2012). In fact, De Souza et al. (2010) reported that a greater proportion of Brazilian ungraduated Catholic students accept biological evolution when compared to their Protestant peers. According to Pennock (2003, p. 144), Catholics "do not consider evolution to be in conflict with Christian faith, holding that God could have ordained the evolutionary mechanism as the process for creating the biological world". Therefore we believe that religiousness might not have a major influence in Brazilian students' views of the origins of human behavior. On the other hand, we hypothesize that evolutionist beliefs favor acceptance of naturebased explanation of human behavior.

3. What, if any, are the differences among students' views of the various aspects of human behavior?

Normally people believe that social behavior is reinforced by social interactions. Thus, we hypothesize that the students will favor explanations of human social behaviors supported by nurture arguments.

\section{Methods \\ Sample}

Students who took part in this study attended the Federal University of Rio de Janeiro (UFRJ), Rio de Janeiro, Brazil in the year 2005. A sample of 1212 students (63\% females and $34 \%$ males) answered the Human Behavior Questionnaire (HBQ). These students were recruited among freshmen and seniors from 16 different careers (Arts $\mathrm{n}=44$, Biology $\mathrm{n}=109$, Education $\mathrm{n}=183$, Engineering $\mathrm{n}=157$, History $\mathrm{n}=88$, Geography $\mathrm{n}=47$, Immunology $\mathrm{n}=54$, Literature $\mathrm{n}=50$, Medicine $\mathrm{n}=108$, Meteorology $n=20$, Pharmacology $n=84$, Philosophy $\mathrm{n}=28$, Physics $\mathrm{n}=39$, Physiotherapy $\mathrm{n}=43$, Psychology $\mathrm{n}=94$ and Social Sciences $\mathrm{n}=44$ ). There was no statistical difference $(\mathrm{F}=1.2456 ; \mathrm{P}=0.2646)$ between global means of freshmen and senior students (see "The Human Behavior Questionnaire (HBQ)" for details on global mean calculations). The whole group of students was therefore analysed as a single sample.

An additional sample of 255 students (51\% female, $49 \%$ male) answered to the questionnaire on Shared Behavior (SBQ; see detail below). They were recruited among freshmen from four different careers (Arts $n=22$, Biology $n=39$, Engineering $n=104$, Medicine $n=30$, Psychology $\mathrm{n}=60$ ).

The mean age and standard deviation of all participants were of $21.87 \pm 5.21$. All students answered anonymously to printed versions of the questionnaires in their own classrooms without a limited set time. Questions from the students when filling out questionnaires were instantly clarified by the researchers in charge. A written informed consent was signed by respondents prior to answering all questionnaires.

\section{The Human Behavior Questionnaire (HBQ)}

The first two questions of the questionnaire on human behavior (HBQ) referred to religious beliefs and to the acceptance of human evolution. In both cases, it was necessary for students to choose an integer between 1 and 7 . Concerning the question on religiosity, number 1 meant considering oneself an atheist and number 7 as extremely religious. As to the question on human evolution, number 1 meant complete disagreement with the idea of a common ancestor for both the human species and all other living creatures, whereas number 7 meant a total agreement with that concept.

The remaining questions of the HBQ assessed the students' opinions about the origins of the six types of human behavior (see below). Both nature and nurturebased origins of human behavior were previously defined in the headings of each question on behavior.

The six types of behavior analysed using HBQ were: human sexual behavior ("sex" for short), love, altruism, violence, forms of interpreting reality (this we called "mind"), and personality traits. The choice of the six types of behavior to be included in the questionnaire was based on the extensive existing scientific literature on their appropriate evolutionary bases (Hagen 2005; Laland and Brown 2002; Ridley 2003). In order to facilitate the perception of both acquired experience and genetic factors, a broad definition of each of the six behaviors was included at the beginning of the respective question. Definitions were freely adapted from Brazilian dictionaries. See Additional file 1 for more details.

Students were required to mark an integer, between 1 and 7 for each question. It was explicitly stated that the number 1 meant that the origin of a specific behavior was 
exclusively explained by genetic factors, whereas number 7 meant that it was exclusively acquired by experience.

The mean of the answers to the six questions on behavior (Student's Individual Mean: SIM) was calculated for each student. The SIM expressed the general opinion of each student on the origins of the six types of behavior. We also calculated the mean of the SIM (hereinafter denominated Global Mean or GM), which represents the global view from our sample of the six types of behavior. The mean value for the answers to each question on behavior [behavioral mean (BM)] was also calculated.

\section{The Shared Behavior Questionnaire (SBQ)}

The SBQ was intended to assess the student's opinion on what extent four specific types of behavior [sexual behavior (sex), altruism, love and violence] are shared with all other animal species. As in the HBQ, each behavior was also defined and students were asked to assign an integer between 1 (the specific behavior was shared with all animals) and 7 (the behavior was exclusively human). See Additional file 2 for details. The average for each behavior (the Shared Behavior Mean or SBM) was calculated and compared with each other as well as with the means from control questions (see below). A total of 255 undergraduate students responded to the SBQ.

\section{Questionnaires' Validation}

Two control questions were included in the HBQ: the first concerned the inheritance of blood type in the $A B O$ system (an exclusively genetic inheritance) whereas the second concerned the acquisition of a native idiom (a behavior acquired exclusively through experience). The mean value of the "blood type" $(1.11 \pm 0.43)$ and "native idiom" $(6.34 \pm 1.21)$ questions were very close to their expected values of 1 and 7 respectively, showing that students could clearly distinguish between genetically inherited and learned characteristics.

In addition two questions were included as controls in SBQ. Respiration is shared with all animals whereas writing occurs exclusively in humans. The mean values obtained for the "respiration" $(1.76 \pm 1.16)$ and "writing" $(6.66 \pm 0.78)$ were very close to their expected values of 1 and 7 respectively, showing that students could clearly distinguish between characteristics shared with other animals from those exclusive of human beings.

A sample of 51 students answered the questionnaires twice within an interval of 70 days between tests and retests. The means of 50 of those students presented were not statistically different (all $\mathrm{P}$ values $<0.05$, paired $\mathrm{t}$ tests used in all comparisons).

Taken together, those results suggested that the questionnaires were ready to be used for data collection.

\section{Data Analysis}

In order to compare GM with the means of control questions we ran an ANOVA for repeated measures along with a Tukey post hoc test and a sequential Bonferroni adjustment for multiple comparisons (Zar 1996). The same procedure was used to compare the different $B M$ (from HBQ) and SBM (from SBQ). Effect size was calculated for each mean comparison following Cohen's $d$ statistics, using the pooled standard deviation (Cohen 1992).

Polychoric correlations were performed to test association between values for religiosity and evolutionism. Associations between values for religiosity and SIM, as well as between values for evolutionism and SIM were calculated by polyserial correlations (Olsson et al. 1982; Garrido et al. 2013).

\section{Results}

Where, in the Nature-Nurture Continuum, Lie the Students' Views on the Origins of Human Behavior? Global means (GM) and means for each control question are shown in Fig. 1. Blood type had the lowest mean while native idiom had the highest. The GM was intermediate to both the controls. The three means differed statistically (ANOVA: $\mathrm{F}_{2,1252}=6,661.513, \mathrm{P}<0.001, \mathrm{~d}$ from 1.09 to 6.41 ). These data indicate that in general students could properly identify and discriminate genetic (blood type) from acquired inheritance (native idiom). The GM value (5.31) therefore allows to infer that students preferred nurture-based explanations as a general explanation for the origins of human behavior rather than nature-based explanations since the GM was much closer to 7 than to 1 and was higher than 4 , the intermediate value of the adopted scale.

The latter conclusion becomes clearer when grouping students into three categories according to individual means (SIM): Naturalistic students seemed to favor nature-based explanations $(\mathrm{SIM}<3)$; intermediate

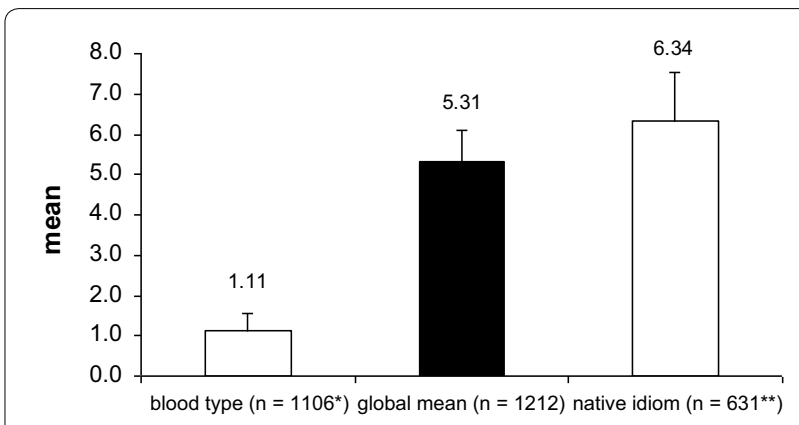

Fig. 1 Means and standard deviation for control questions (white bars) and global mean (black bar). * The lower number of answers on blood type is due to unanswered questions. ${ }^{*}$ In the beginning of the survey, there was only one control question (blood type). 
students considered both types of explanation to be equally important (SIM varying between 3 and 5) and experientialist students seemed to favor nurture-based explanations of human behavior (SIM > 5). The majority of the students were experientialists (61.72\%), thereby supporting the idea that most of them have a "nurture" view of the origins of human behaviors (Fig. 2). This conclusion is further reinforced by the finding that 128 students (11\%) showed SIM equal to or above the mean (SIM $\geq 6.34)$ for the control question on 'native idiom' and none showed a mean lower than the mean control question on 'blood type' (SIM < 1.11).

\section{What, if any, are the Influences of Religiosity and/or of the Acceptance of Human Evolution on the Students' Views of the Origins of Human Behavior?}

Results from questions on religiosity (Mean $=3.89$, $\mathrm{SD}=1.70, \mathrm{~N}=1143$ ) and human evolution (Mean $=5.03, \mathrm{SD}=2.02, \mathrm{~N}=1143$ ) from the HBQ suggest that many students had some sort of religious belief and were committed to the idea of a human phylogenetic history. A significant but weak negative polychoric correlation was found between religiosity and evolutionary commitments $(\mathrm{r}=-0.333, \mathrm{~N}=1143, \mathrm{SE}=0.028)$. These results indicated that students who gave credence to human evolution also tended to assume weaker religious commitments.

Polyserial correlations between SIM and the values for questions on religiosity were not significant $(r=0.005$, $\mathrm{N}=1143, \mathrm{SE}=0.031)$ as well as for SIM and questions on evolution $(\mathrm{r}=-0.027, \mathrm{~N}=1155, \mathrm{SE}=0.032)$, thereby suggesting that none of these commitments are, per se, sufficient to explain students' conceptions on the origins of human behavior.

\section{What, if any, are the Differences Among Students' Views of the Various Aspects of Human Behavior?}

In order to answer this question, the six behavioral means (BM) were compared using an ANOVA for repeated measures. All BM were very close to or higher than 5.0, thus indicating that students tended to accept

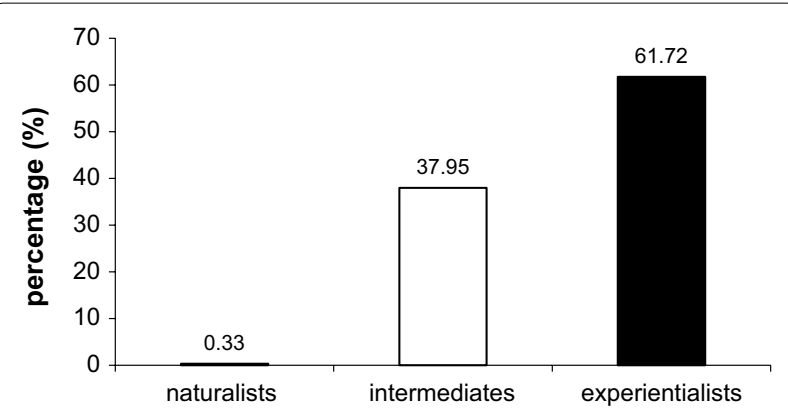

Fig. 2 Student's individual means (SIM) distribution $(n=1,212)$. nurture-based more than nature-based explanations for all behavioral forms in HBQ (Fig. 3). Nevertheless, BM were statistically different $\left(\mathrm{F}_{5,6055}=107.102, \mathrm{P}<0.0001\right)$ suggesting that not all behaviors were considered as equally influenced by nurture-based explanations. The Tukey post hoc test with Bonferroni's correction indicated that questions showing the highest $\mathrm{BM}$ (love and altruism) differed from all the others $(\mathrm{P}<0.0001$ in all comparisons, $\mathrm{d}$ from 0.29 to 0.64$)$, but were not statistically different from each other $(\mathrm{P}=0.147)$. Furthermore, the BM for violence was different from the other five behavior types $(\mathrm{P}<0.0001$ in all comparisons, $\mathrm{d}$ from 0.14 to 0.38 ), whereas means for the three questions with lower BM (human sexual behavior (sex), forms of reality interpretation (mind) and personality traits) were not statistically different from one another.

In attempting to explain these results, we formulated the hypothesis that students who chose values close to 7-behaviors best explained by acquired experiencewould consider these as exclusively human. Following the same line of reasoning, BM with lower values indicates that a student considers a given behavior as part of both human and animal features. This hypothesis is based on the idea that human beings possess higher learning abilities, acquired from intense and complex socialization. Following this rationale, we believe that students probably think that social behaviors considered specific to human beings would thus be better explained through nurture reasoning than behaviors shared with other animals.

Data from SBQ questionnaires were used to test this hypothesis (Fig. 4). Results from the ANOVA for repeated measure for control questions infer that students could identify and discriminate writing, a behavior exclusive to human, from respiration, a behavior that is shared with all other animals $\left(\mathrm{F}_{1,249}=2,992.59 ; \mathrm{P}<0.0001, \mathrm{~d}=4.95\right)$. All other four shared behavior means (SBM) are lower than 4, implying that students consider all these behaviors to be shared with other animals.

Nevertheless, SBM also differed statistically $\left(\mathrm{F}_{3,702}=57.09, \mathrm{P}<0.001\right)$. The Tukey post hoc test with Bonferroni correction indicated that behaviors grouped statistically within the SBQ were the same as those observed for the BMs in the HBQ. Love and altruism manifested the highest SBM with no statistical difference between them $(P=1.000)$, and differed from the $\mathrm{BM}$ of sexual behaviour and violence $(\mathrm{P}<0.020$, for all comparisons, $\mathrm{d}$ from 0.26 to 1.08 ). Furthermore, sexual behavior and violence SBM are both significantly distinct from each other and significantly distinct from the other behaviors $(\mathrm{P}<0.020$ in all comparisons, $\mathrm{d}$ from 0.26 to 0.61 ). Hence, the hypothesis that students believe that human social behaviors (such as love and altruism) are 


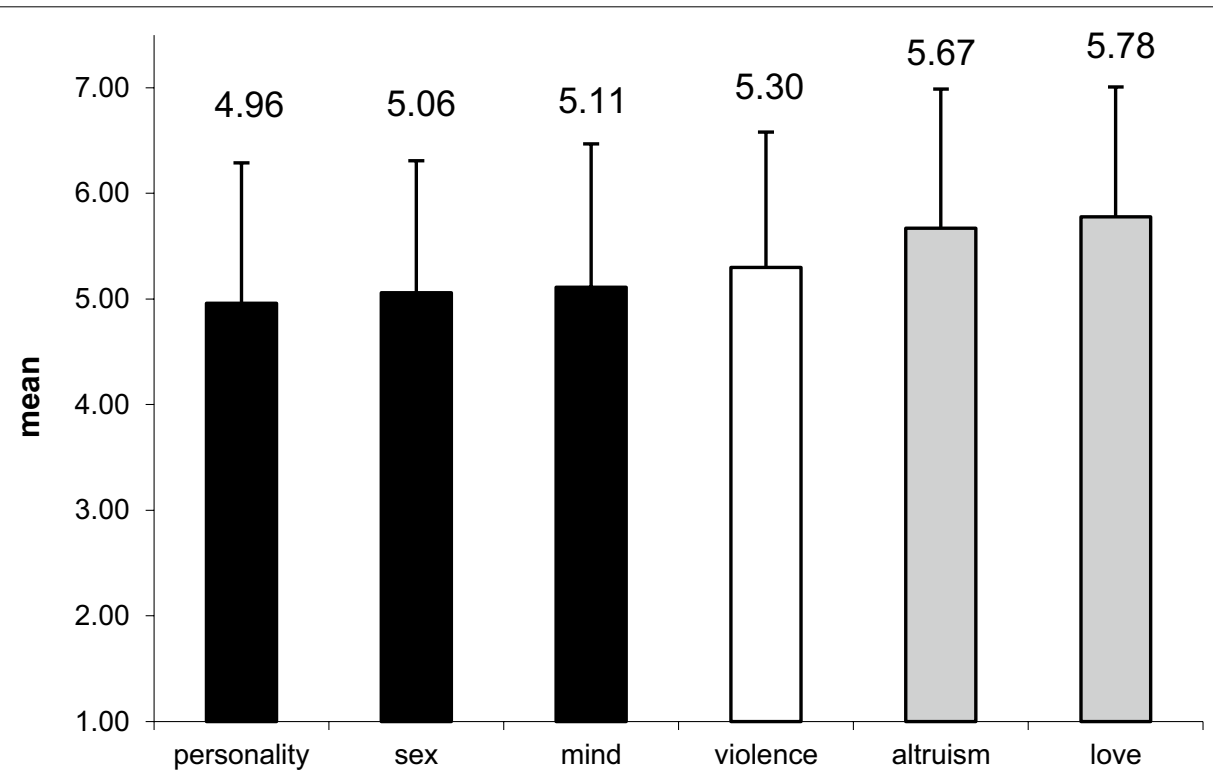

Fig. 3 Behavior means and standard deviations. Like-colored bars indicate statistically equal means $(n=1,212)$.

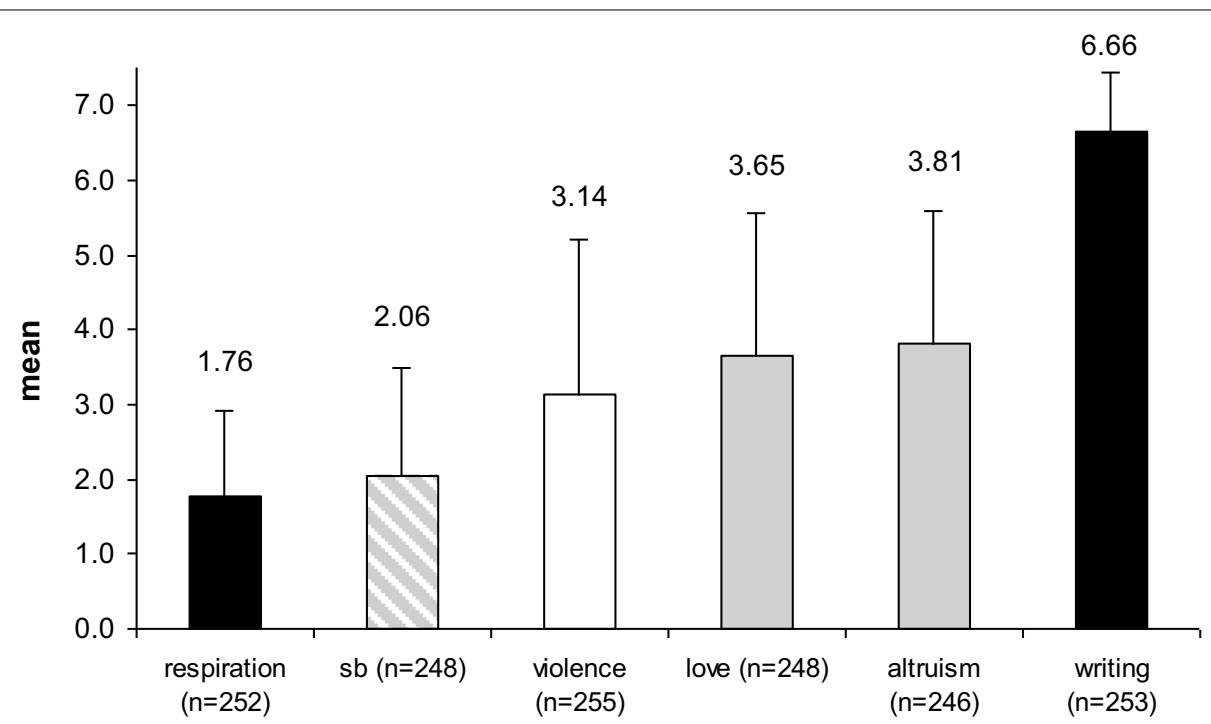

Fig. 4 Control questions (black bars), shared behavior means and standard deviations. For SBM, like-colored bars indicate statistically equal means. The different $\mathrm{n}$ is due to blank answers.

best explained through nurture explanations because they were considered typically human was partially supported by the data reported above.

\section{Discussion}

\section{Students' View of the Origins of Human Behavior}

Our main goal in this work was to characterize students' views on the origins of human behavior. Some researchers (Jablonka and Lamb 2005; Laraia 2003 [1986]) believe that people are more receptive to naturebased explanations, whereas other authors believe the opposite (e.g., Pinker 2002). Moreover, Bateson (2001) states that the public in general supports an intermediate view. The results presented here corroborate the second line of thinking: students clearly preferred nurture-based explanations for the origins of the human behaviors 
analysed. We understand that this is probably due to the absence of human behavior in most Brazilian high-school biology textbooks (Silva-Porto et al. 2007). We speculate that this absence may still reflect the reaction to studies on human behavior based on alleged racial traits that flourished during the first half of the twentieth century (Segerstrale 2000). It would be of great interest if studies similar to ours could be further carried out in educational contexts where human behavior (or at least animal behavior) is part of the conventional curriculum.

We are well aware that our results may be somewhat biased, since our sample was restricted to undergraduate students with a mean age of approximately 22 years old. Indeed, groups with similar educational backgrounds and age ranges have favored nurture-based explanations more frequently (Furnham et al. 1985).

\section{Religious and Evolutionism Commitments and the Origins of Human Behavior}

Brazilian students' receptivity to evolution is inversely correlated to their religiosity. These data are in accordance with previous research performed in the USA (Pazy-Miño-C and Espinosa 2012; Heddy and Nadelson 2013; Carter and Wiles 2014; Rissler et al. 2014) and Scotland (Southcott and Downie 2012). However, we found no correlation between the values for individual evolutionary commitments and students acceptance of evolutionary explanations for human social behaviors (inferred from SIM values). Paz-y-Miño-C and Espinosa (2012) found similar results for general faculty, educators of prospective teachers (most of them holding a PhD degree), and students from New England, USA. In their research, $94 \%$ of the general faculty, $75 \%$ of the educators, and $63 \%$ of the students said they accepted evolution openly. Moreover $82 \%$ of the general faculty, $71 \%$ of the educators, and $58 \%$ of the students thought that evolution is definitely true and the evolution of all living organisms from a common ancestor is widely accepted at near $90 \%$ of the whole sample. However, " $15 \%$ of the general faculty, $32 \%$ of the educators, and $35 \%$ of the students believed, incorrectly, that the origin of the human mind cannot be explained by evolution" (Paz-y-Miño-C and Espinosa 2012, p. 139). Ours results and those of Paz$\mathrm{y}$-Miño and Espinosa suggest that accepting evolution as a general principle offers no guarantee for accepting nature-based explanations of human behavior. This phenomenon may be explained by the perception that the acceptance of evolution gives rise to negative feelings, such as a reduced sense of purpose, increased racial discrimination, and selfishness (Brem et al. 2003).

We also found no correlation between the degree of religious commitments and the students' individual means (SIM). In other words, religiosity seems to have no influence in students' view of the origins of human behavior. At first glance, this result seems to be at odds with the data from Furnham et al. (1985). However, all significant differences reported by those authors were due to the fact that Protestants held stronger naturalistic views than agnostics and atheists. Protestants represented $43 \%$ of their sample, but only $22.2 \%$ of the Brazilian population, consisting of $65 \%$ of Catholics (IBGE 2010). It is possible that the effect of Catholicism on the acceptance of the evolutionary influence on human social behavior is less pronounced.

\section{Students' View of the Various Aspects of Human Behavior}

In the present study, the highest means in both the HBQ and SBQ were assigned to love and altruism, implying students' preference for nurture-based explanations of social behaviors that are believed to be more typically and uniquely human. Therefore, the idea that social behaviors such as love and altruism are better explained by nurturebased explanations may have become widespread, while nature-based explanations would be considered slightly more important in individual human abilities.

\section{Implications for Biology Curriculum}

The science curriculum has been long seen as overloaded (Vogel 1996; Newton et al. 1999), raising a question that seems difficult to answer: Where and how to insert the behavior content?

We suggest two complementary approaches that could improve students' understanding of the evolutionary basis of human social behavior. The first would be to highlight the influence of both evolutionary and social factors in relevant social issues (e.g. the obesity epidemics). Secondly, one could directly address the evolutionary basis of a human social behavior (e.g. altruism).

Increased rates of obesity and overweight are now believed to have become a global public health problem (WHO 2014). It is postulated that genes related to efficient food collection and fat deposition helped early humans to survive periods of famine and were thus positively selected (see Power 2012 for a review). In the last century carbohydrates and fats became very cheap in industrial societies. Our innate preferences for sweet, soft and hot food-inherited from our ape common ancestors (Wrangham 2009)-led to substantial increase in the fat and carbohydrate composition of human diet in association with a reduction in the energy expenditure associated with food collection (Bellisari 2008; Power and Schulkin 2009; Cordain et al. 2005). Those cultural changes happened far too quickly to be accompanied by evolutionary (genetic) changes leading to increased rates 
of overweight and obesity (Power 2012). The worldwide increase in obesity thus represents an excellent opportunity to discuss the mutual influence of the nature and nurture factors on a topic that is both socially and biologically relevant.

Scholars agree about the importance of biological evolution as one of the determinants of altruism and cooperation (reciprocal altruism) in human species, even if they may diverge on the level at which natural selection acts to explain the evolution of altruism (see Wilson 2012 for a review). We suggest focusing on altruism and cooperation while also emphasizing the feelings of justice, punishment and guilt that may have evolved in order to stabilize cooperation (Trivers 1971). There are experiments with cleaner and coral fishes (Bshary and Schaffer 2002) and capuchin monkeys (de Waal and Berger 2000; Bronsnan and de Waal 2003) that demonstrate that altruism and cooperation have evolved between species as well as among social species. We believe that the acceptance of nature-based explanations of human behavior by high school students would be more easily achieved if teachers focus on simple empirical work done with other social animals. Although Brazilian students show more difficulty on accepting the biological bases of altruism, it would be more appropriate to discuss its evolutionary bases instead of those behaviors in which the evolutionary bases are already well accepted by them.

\section{Conclusion}

We conclude that, despite the enormous influence of evolutionary theory on recent western thought, Brazilian students do not seem to perceive its implications for the origins of human social behavior. We believe that this knowledge gap is not a matter of minor importance. Evidence brought up recently by different evolutionary behavioral scientific fields such as sociobiology, behavioral ecology, gene-culture coevolution, and evolutionary psychology suggests that, although human behavior is flexible, it is not infinitely malleable (see Laland and Brown 2002, for a review). Furthermore, some authors argue that human plasticity itself is an evolutionary acquisition (Tooby and Cosmides 1992). Therefore, a better knowledge of human nature should be one of the grounds to address strategies for realistic social changes (Singer 1999).

\section{Additional Files}

Additional file 1: Human behavior questionnaire.

Additional file 2: Shared behavior questionnaire.

\section{Authors' contributions}

FCSP, PCP, RW and MRMPL shared all responsibilities related to research, analysis, and drafting of the manuscript. All authors read and approved the final manuscript.

\section{Author details}

${ }^{1}$ Colégio de Aplicação, Universidade Federal do Rio de Janeiro, Rua Batista da Costa, 55, Lagoa, Rio de Janeiro, RJ CEP: 22470-130, Brazil. ${ }^{2}$ Departamento de Zoologia, Instituto de Biologia, Universidade Federal do Rio de Janeiro, CCS-Bloco A-Ilha do Fundão, Rio de Janeiro, RJ CEP: 21941-590, Brazil. ${ }^{3}$ Laboratório de Avaliação em Ensino e Filosofia das Biociências, Instituto Oswaldo Cruz, Av. Brasil, 4365-Pavilhão 108, sala 31 Manguinhos, Rio de Janeiro, RJ CEP: 21040-360, Brazil.

\section{Acknowledgements}

The present work was supported by grants from the Fundação Carlos Chagas Filho de Amparo à Pesquisa do Estado do Rio de Janeiro (FAPERJE-26/110.546/2014 and E-26/100.583/2014) and Conselho Nacional de Pesquisa (CNPq-481714/2013-8). The authors thank the editors and two anonymous reviewers for their helpful criticism and Claudia Kamel for revising the manuscript.

\section{Compliance with Ethical Guidelines}

\section{Competing Interests}

The authors declare that they have no competing interests.

Received: 27 February 2015 Accepted: 5 August 2015

Published online: 14 August 2015

\section{References}

Alles, D. L., \& Stevenson, J. C. (2003). Teaching human evolution. The American Biology Teacher, 65(5), 333-339.

Barkow, J., Cosmides, L., \& Tooby, J. (1992). The adapted mind: evolutionary psychology and the generation of culture. New York: Oxford University Press.

Bateson, P. (2001). Where does our behavior come from? Journal of Biosciences, 26(5), 561-570.

Bellisari, A. (2008). Evolutionary origins of obesity. Obesity Reviews, 9(2), $165-180$.

Besterman, H., \& Baggot la Velle, L. (2007). Using human evolution to teach evolutionary theory. Journal of Biological Education, 41(2), 76-81.

Bourdieu, P. (1998). The economy of symbolic goods. In P. Bourdieu (Ed.), Practical reason: on the theory of action. Stanford: Stanford University Press.

Brem, S. K., Ranney, M., \& Schindel, J. (2003). Perceived consequences of evolution: college students perceive negative personal and social impact in evolutionary theory. Science and Education, 87(2), 181-206.

Bronsnan, S. F., \& De Waal, F. B. M. (2003). Monkeys reject unequal payment. Nature, 425, 297-299.

Bshary, R., \& Schaffer, D. (2002). Choosy reef fish select cleaner fish that provide high-quality. Service Animal Behaviour, 63, 557-564.

Buller, D. J. (2005). Evolutionary psychology: the emperor's new paradigm. Trends in Cognitive Sciences, 9(6), 277-283.

Buss, D. (2005). Handbook of evolutionary psychology. New Jersey: John Wiley \& Sons.

Carter, B. E., \&Wiles, J. R. (2014). Scientific consensus and social controversy: exploring relationships between students' conceptions of the nature of science, biological evolution, and global climate change. Evolution: Education and Outreach, 7,6.

Cohen, J. (1992). A power primer. Psychological Bulletin, 112(1), 155-159.

Cordain, L., Eaton, S. B., Sebastian, A., Mann, N., Lindeberg, S., Watkins, B. A., et al. (2005). Origins and evolution of the western diet: health implications for the 21st century. American Journal of Clinical Nutrition, 81(2), 341-354.

De Waal, F. B. M. (1999). The end of nature versus nurture. Scientific American, 281(6), 94-99.

De Waal, F. B. M. (2005). Our inner ape-a leading primatologist explain why we are who we are. New York: Riverhead Books. 
De Waal, F. B. M., \& Berger, M. L. (2000). Payment for labor in monkeys. Nature, 404, 563.

Furnham, A., Johnson, C., \& Rawles, R. (1985). The determinants of beliefs in human nature. Personality and Individual Differences, 6(6), 675-684.

Garrido, L. E., Abad, J. A., \& Ponsoda, V. (2013). A new look at horn's parallel analysis with ordinal variables. Psychological Methods, 18(4), 454-474.

Gould, S. J. (1996). The mismeasure of man. New York: W. W. Norton.

Gould, S. J., \& Lewontin, R. (1979). The spandrels of San Marco and the panglossian paradigm. Proceedings of the Royal Society of London B: Biological Sciences, 205(1161), 581-598.

Hagen, E. H. (2005). Controversial issues in evolutionary psychology. In D. Buss (Ed.), Handbook of evolutionary psychology (pp. 145-173). New Jersey: John Wiley \& Sons.

Hamilton, W. D. (1964). The genetical evolution of social behaviour. Journal of Theoretical Biology, 7(1), 1-16.

Heddy, B. C., \& Nadelson, L. S. (2013). The variables related to public acceptance of evolution in the United States. Evolution: Education and Outreach, $6(1), 3$.

Instituto Brasileiro de Geografia e Estatística IBGE. (2010). Pesquisa nacional por amostra de domicílio. Censo demográfico. http://oglobo.globo.com/ infograficos/censo-religiao/. Accessed 08 Jun 2015.

Jablonka, E., \& Lamb, M. (2005). Evolution in four dimensions - genetic, epigenetic, behavioural, and symbolic variation in the history of life. Cambridge: Massachusetts Institute of Technology Press.

Krebs, D. L. (2003). Fictions and facts about evolutionary approaches to human behavior. Psycho Bull, 129(6), 842-847.

Laland, K. N., \& Brown, G. R. (2002). Sense and nonsense: evolutionary perspectives on human behaviour. Oxford: Oxford University Press.

Laraia, R. B. (2003). Cultura: um conceito antropológico (16th ed.). Rio de Janeiro: Jorge Zahar.

Lickliter, R., \& Honeycutt, H. (2003a). Developmental dynamics: toward a biologically plausible evolutionary psychology. Psychological Bulletin, 129(6), 819-835.

Lickliter, R., \& Honeycutt, H. (2003b). Developmental dynamics and contemporary evolutionary psychology: status quo or irreversible views? Reply to Bjorklund (2003), Krebs (2003), Buss and Reeve (2003), Crawford (2003) and Tooby et al. (2003). Psychological Bulletin, 129(6), 866-872.

Mayr, E. (1982). The growth of biological thought: diversity, evolution, and inheritance. Cambridge: Harvard University Press.

Newton, P., Driver, R., \& Osborne, J. (1999). The place of argumentation in the pedagogy of school science. International Journal of Science Education, 21(5), 553-576.

Nickels, M. (1998). Humans as a case study for the evidence of evolution. Reports on the National Center for Science Education, 18(5), 24-27.

Olsson, U., Drasgow, F., \& Dorans, N. J. (1982). The polyserial correlation coefficient. Psychometrika, 47, 337-347.

Parrott, R. L., Silk, K. J., \& Condit, C. (2003). Diversity in lay perceptions of the sources of human traits: genes, environment, and personal behaviors. Social Science and Medicine, 56(5), 1099-1109.

Paz-y-Miño-C, G., \& Espinosa, A. (2012). Educators of prospective teachers hesitate to embrace evolution due to deficient understanding of science/evolution and high religiosity. Evolution: Education and Outreach, 5 , $139-162$.

Pennock, R. T. (2003). Creationism and intelligent design. Annual Review of Genomics and Human Genetics, 4, 143-163.

Penteado, P. R., Kavalco, K. F., \& Pazza, R. (2012). Influence of sociocultural factors and acceptance of creationism in the comprehension of evolutionary biology in Freshman Brazilian students. Evolution: Education and Outreach, 5, 589-594.

Pinker, S. (2002). The blank slate: the modern denial of human nature. New York: Penguin Books.

Power, M. L. (2012). The human obesity epidemic, the mismatch paradigm, and our modern "captive" environment. American Journal of Human Biology, 24(2), 116-122.

Power, M. L., \& Schulkin, J. (2009). The evolution of obesity. Baltimore: John Hopkins University Press.

Ridley, M. (2003). Nature via nurture: genes, experience, and what makes us human. New York: Harper Collins Publishers.

Rissler, L. J., Duncan, S. I., \& Caruso, N. M. (2014). The relative importance of religion and education on university students'views of evolution in the
Deep South and state science standards across the United States. Evolution: Education and Outreach, 7, 24.

Rose, H., \& Rose, S. (2000). Alas, poor Darwin: arguments against evolutionary psychology. New York: Harmony Books.

Rowland, G. (2007). Towards a new biology curriculum. Journal of Biological Education, 41(3), 99-101.

Segerstrale, U. (2000). Defenders of the truth: the sociobiology debate. Oxford: Oxford University Press.

Silva-Porto F, Luz MRMP, Waizbort R (2007) A suposta centralidade da evolução nos livros didáticos de biologia. Paper presented at the 6th meeting of the Brazilian Association of Research in Science Education (VI ENPEC), Florianópolis, Santa Catarina, Brazil. http://www.nutes.ufrj.br/abrapec/ vienpec/CR2/p430.pdf. Accessed 12 Dec 2014.

Singer, P. (1999). A darwinian left: politics, evolution and cooperation. New Haven and London: Yale University Press.

Singer, E., Corning, A., \& Lamias, M. (1998). The polls-trends: genetic testing, engineering, and therapy: awareness and attitudes. Public Opinion Quarterly, 62(4), 633-664.

Southcott, R., \& Downie, J. R. (2012). Evolution and religion: attitudes of Scottish Bioscience students to the teaching of evolutionary biology. Evolution: Education and Outreach, 5, 301-311.

Souza, R. F., Carvalho, M., Matsuo, T., \& Zaia, D. A. M. (2010). Study on the opinion of university students about the themes of the origin of Universe and evolution of life. International Journal of Astrobiology, 9(2), 109-117.

Stepan, N. L. (2005). A hora da eugenia: raça, gênero e nação na América Latina. Rio de Janeiro: Editora Fiocruz.

Tooby, J., \& Cosmides, L. (1992). The psychological foundations of culture. In J. Barkow, L. Cosmides, \& J. Tooby (Eds.), The adapted mind: evolutionary psychology and the generation of culture (pp. 19-136). New York: Oxford University Press.

Tooby, J., Cosmides, L., \& Barret, C. H. (2003). The second law of thermodynamics is the first law of psychology: evolutionary developmental psychology and the theory of tandem, coordinated inheritances: Comment on Lickliter and Honeycutt (2003). Psychological Bulletin, 129(6), 858-865.

Tremblay, T., \& Gagné, F. (2001). Beliefs of students talented in academics, music, and dance concerning the heritability of human abilities in these fields. Roeper Review, 23(3), 173-177.

Trivers, R. L. (1971). The evolution of reciprocal altruism. Quarterly Review of Biology, 46(1), 35-57.

Trivers, R. L. (1972). Parental investment and sexual selection. In B. Campbell (Ed.), Sexual selection and the descent of man 1871-1971 (pp. 136-179). Chicago: Aldine-Atherton.

Vogel, G. (1996). Global review faults US curricula. Science, 274(5286), 335.

WHO-World Health Organization. (2014). Obesity and overweight. Fact sheet No311 updated August 2014. http://www.who.int/mediacentre/ factsheets/fs311/en/. Accessed 19 Dec 2014.

Wilson, E. O. (1975). Sociobiology: the new synthesis. Cambridge: The Belknap Press of Harvard University Press.

Wilson, E. O. (2012). The social conquest of Earth. New York: Liveright Publishing Corporation.

Wrangham, R. (2009). Catching fire: how cooking made us human. New York: Basic Books.

Zar, J. H. (1996). Biostatistical analysis (3rd ed.). New Jersey: Prentice Hall.

\section{Submit your manuscript to a SpringerOpen ${ }^{\odot}$ journal and benefit from:}

- Convenient online submission

- Rigorous peer review

- Immediate publication on acceptance

- Open access: articles freely available online

- High visibility within the field

- Retaining the copyright to your article

Submit your next manuscript at springeropen.com 